\title{
c-ANCA positivity in a patient with relapsing polychondritis: Co-incidence or not? A case and review of the literature
}

\author{
Tekrarlayan polikondritli bir hastada c-ANCA pozitifliği: Birliktelik mi, değil mi? Bir olgu ve literatürün \\ gözden geçirilmesi
}

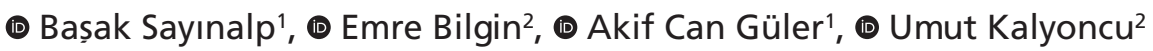 \\ ${ }^{1}$ Hacettepe University Faculty of Medicine, Department of Internal Medicine, Ankara, Turkey \\ 2 Hacettepe University Faculty of Medicine, Department of Internal Medicine, Division of Rheumatology, Ankara, Turkey
}

\begin{abstract}
Relapsing polychondritis (RP) is a rare immune-mediated disease that is characterized by recurrent inflammation of cartilaginous and proteoglycan-rich tissues. The most frequent involved sites are the auricular cartilage and cartilage of peripheral joints. Approximately one third of RP cases are associated with other diseases, such as vasculitis, connective tissue diseases and myelodysplastic syndrome. Herein we present a RP case that was found positive for cytoplasmic antineutrophil cytoplasmic antibody (c-ANCA or PR3-ANCA) but did not show any signs of systemic ANCA-associated vasculitis. It is important to make sure that RP patients are being investigated for the presence of any associated disease and followed up accordingly.

Keywords: Relapsing polychondritis, antineutrophil cytoplasmic antibody, review
\end{abstract}

\section{Öz}

Tekrarlayan polikondrit (RP), kıkırdak ve proteoglikandan zengin dokuların tekrarlayan enflamasyonu ile karakterize, nadir görülen immün aracılı bir hastalıktır. En sık tutulan bölgeler kulak kıkırdağı ve periferik eklemlerin kıkırdağıdır. RP olgularının yaklașık üçte biri vaskülit, bağ dokusu hastalıkları ve myelodisplastik sendrom gibi diğer hastalıklarla ilișkilidir. Burada sitoplazmik antinötrofil sitoplazmik antikor (c-ANCA veya PR3-ANCA) pozitif bulunan ancak herhangi bir sistemik ANCA ilișkili vaskülit belirtisi göstermeyen bir RP olgusu sunuyoruz. RP hastalarının herhangi bir ilișkili hastalık varlığı açısından araștırıldıklarından ve buna göre takip edildiklerinden emin olmak önemlidir.

Anahtar Kelimeler: Tekrarlayan polikondrit, antinötrofil sitoplazmik antikor, derleme

\section{Introduction}

Relapsing polychondritis (RP) is an immune-mediated disease that involves cartilaginous and proteoglycanrich tissues such as the elastic cartilage of the ear and nose, the cartilage of the tracheobronchial tree and the hyaline cartilage of peripheral joints. It is characterized by recurrent inflammatory episodes of these tissues, which result in deformation and functional impairment. The most frequent presentation of RP is auricular chondritis and polyarthritis, which are seen in over $80 \%$ of patients. There are different diagnostic criteria of RP according to different authors. ${ }^{[1]}$ Criteria suggested by McAdam et al. ${ }^{[2]}$ in 1976 is the most popular and requires the presence of at least three of six clinical features including auricular chondritis, nonerosive inflammatory polyarthritis, nasal chondritis, ocular inflammation, respiratory tract chondritis and audiovestibular damage. ${ }^{[1,2]}$ It is known that approximately one third of RP cases are associated with other diseases, such as vasculitis, rheumatoid arthritis, connective tissue diseases and malignancies, especially myelodysplastic syndrome. ${ }^{[3,4]}$

İletișim / Correspondence:

Specialist. Emre Bilgin, Hacettepe University Faculty of Medicine, Department of Internal Medicine, Division of Rheumatology, Ankara, Turkey

Tel.: +90 3123051148 E-posta: dr.emrebilgin@gmail.com ORCID ID: orcid.org/0000-0002-2260-4660

Geliș Tarihi / Received: 18.12.2019 Kabul Tarihi / Accepted: 04.02.2020

Atıf / Cite this article as: Sayınalp B, Bilgin E, Güler AC, Kalyoncu U. c-ANCA positivity in a patient with relapsing polychondritis: Co-incidence or not? A case and review of the literature. Ulus Romatol Derg 2021;13(2):88-90

๑Telif Hakkı 2021 Türkiye Romatoloji Derneği / Ulusal Romatoloji Dergisi, Galenos Yayınevi tarafından yayınlanmıștır.

${ }^{\circ}$ Copyright 2021 by the Turkish Society for Rheumatology / Journal of Turkish Society for Rheumatology published by Galenos Publishing House. 


\section{Case Report}

A 68-year-old woman who had a history of atrial fibrillation, sick sinus syndrome and Meniere's disease was admitted to our clinic with the complaints of ongoing fever and weakness for one month. She also complained of night sweats and weight loss (8 kilograms in one year). Before being admitted to our hospital, she had two separate hospital admissions with the same symptoms. Her laboratory tests in those admissions had revealed high levels of acute phase reactants and coagulase negative staphylococci had been isolated from her blood cultures. Physical examination had revealed no murmurs and no vegetations or thrombi had been identified on transthoracic echocardiogram. Intravenous antibiotics had been initiated and the patient was referred to our hospital for further evaluation.

On admission, her body temperature was $38.4{ }^{\circ} \mathrm{C}$ and laboratory tests revealed a C-reactive protein level of 26.7 $\mathrm{mg} / \mathrm{dL}(0-0.8)$ and an erythrocyte sedimentation rate of $100 \mathrm{~mm} / \mathrm{h}$. Her complete blood count results were as follows; hemoglobin: $10.3 \mathrm{gr} / \mathrm{dL}$ which was compatible with anemia of chronic disease, leukocyte: $8.4 \times 10^{3} / \mu \mathrm{L}$ and platelet: $428 \times 10^{3} / \mu \mathrm{L}$. No microorganisms were isolated from six different sets of blood culture. A transesophageal echocardiography was performed and a millimetric fibrillary mobile structure was identified on the pacemaker electrode, which had been implanted for sick sinus syndrome, at the junction of superior vena cava and right atrium. Therefore, she was diagnosed with pacemaker-associated infection and intravenous ampicillin and gentamicin was initiated. However, following antibiotic treatment, she continued to experience fever and her acute phase reactant levels remained high despite antibiotic treatment. Computerized tomography angiography did not reveal any specific findings that might be associated with infection, malignancy or vasculitis. Further laboratory tests were performed; ANCA IFA was reported to be positive in 1/100 dilution and PR3ANCA ELISA was positive.

During her hospital stay, she experienced redness, pain and swelling first in her right auricula and within days, similar symptoms developed in her left auricula (Figure 1) along with redness in her left conjunctiva. When questioned, she also complained of a recently developed numbness in her nasal root and difficulty in hearing for almost ten years. An earnose-throat examination was performed, and perichondritis in left auricula and bilateral moderate sensorineural hearing loss were noted. Therefore, she was diagnosed with RP. 48 $\mathrm{mg}$ of methylprednisolone per oral was initiated. Within two days, a decline in her acute phase reactant levels was observed and her fever resolved.

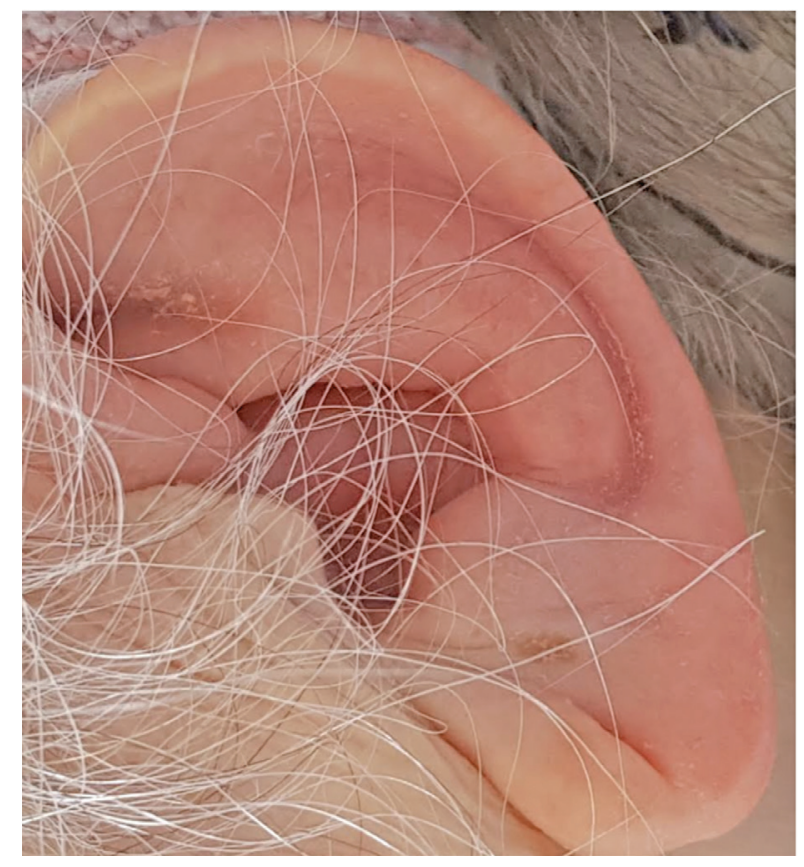

Figure 1. Swelling and redness in left auricula

Since myelodysplastic syndrome can accompany $\mathrm{RP},{ }^{[3]}$ a bone marrow biopsy was performed. However, it was reported as normocellular bone marrow with an increase in megakaryocytes, which supports a reactive process. Therefore, she was discharged with $48 \mathrm{mg}$ methylprednisolone and azathioprine $50 \mathrm{mg}$ bid.

\section{Discussion}

Our patient demonstrated the clinical signs of auricular chondritis, nasal chondritis, ocular inflammation and audiovestibular damage, and therefore according to the criteria suggested by McAdam et al. ${ }^{[2]}$ she was diagnosed with RP. In our case, none of the associated diseases mentioned before accompanied RP: however, PR3-ANCA was positive without any vasculitic manifestations. It is known that ANCA is positive in approximately $25 \%$ of RP patients, and $10 \%$ of these have clinical manifestations of vasculitis. ${ }^{[5]}$ Glycosaminoglycans in cartilage, aorta, sclera, cornea and pinna are the main targets in RP. ${ }^{[6]}$ Also, antineutrophil antibodies seem to have a role in the vascular lesions, leading to enzymatic lysis of glycosaminoglycans. ${ }^{[7]}$ We may hypothesize that production of ANCAs is triggered by the destruction of connective tissue during the disease process of RP.

In Table 1, cases that involve both RP and ANCA positivity can be seen. In addition to these cases, Papo et al. ${ }^{[8]}$ investigated $33 \mathrm{RP}$ cases for ANCA positivity in 1993 and eight cases were found positive, three of them with c-ANCA and five of them with perinuclear-ANCA (p-ANCA or MPO-ANCA).

File at al. ${ }^{[10]}$ reported three cases with p-ANCA positive associated vasculitis (AAV). In the first patient, RP 
Table 1. Cases of RP and ANCA positivity that have been reported so far

\begin{tabular}{|c|c|c|}
\hline $\begin{array}{l}\text { Authors, year and } \\
\text { reference }\end{array}$ & $\begin{array}{l}\text { Number of } \\
\text { patients }\end{array}$ & Conditions that accompany RP \\
\hline Xuan et al. 2017 & 1 & $\begin{array}{l}\text { p-ANCA positivity, Graves disease, } \\
\text { suspected Moyamoya disease } \\
\text { (multiple intracranial vasculopathy) }\end{array}$ \\
\hline File et al. $2014^{[10]}$ & 3 & 3 cases with $p$-ANCA positive AAV \\
\hline $\begin{array}{l}\text { Mattiassich et al. } \\
2013^{[11]}\end{array}$ & 1 & c-ANCA positive AAV \\
\hline Cañas et al. $2011^{[12]}$ & 3 & $\begin{array}{c}3 \text { cases with hypertrophic } \\
\text { pachymeningitis and c-ANCA } \\
\text { positive AAV }\end{array}$ \\
\hline Masterson et al. $2001^{[5]}$ & 1 & $\begin{array}{l}\text { Recurrent p-ANCA positive AAV } \\
\text { leading to renal allograft loss }\end{array}$ \\
\hline
\end{tabular}

developed 1.5 years after the onset of AAV. However, in the other two patients, RP had been diagnosed before AAV which manifested with severe crescentic glomerulonephritis. Mattiassich et al. ${ }^{[1]}$ reported a case of c-ANCA positive systemic and cerebral vasculitis in which a rising c-ANCA titre triggered RP symptoms. After treatment with corticosteroids for RP, cyclophosphamide was given for vasculitis and decrease in c-ANCA titre was observed along with full remission of RP symptoms. In our patient, imaging studies were performed in order to bring any potential underlying vasculitis into light: however, they did not reveal any supportive signs. Moreover, in a case reported by Xuan et al. ${ }^{[9]}$, p-ANCA positivity was secondary to propylthiouracil (PTU) use for Graves' disease. It is known that drugs such as PTU, hydralazine, anti-tumor necrosis factor alpha agents, sulfasalazine, D-penicillamine, antibiotics such as cephotaxime and minocycline can lead to ANCA positivity and even AAV. ${ }^{[13]}$ Therefore, we questioned our patient's drug use but no causal drugs were identified.

To sum up, ANCA positivity can accompany RP and patients should be investigated thoroughly for a primary systemic AAV and be questioned for drug use that may cause ANCA positivity. However, when there are no supportive signs for an underlying vasculitis or drug use as in our case, it is not clear how to do the follow-up of these patients. Therefore, more studies are needed to determine how physicians should follow their RP patients who demonstrate ANCA positivity, and we wanted to emphasize this matter by reporting such a case.

\section{Ethic}

Informed Consent: Written consent was taken from the patient.

Peer-review: Externally peer-reviewed.

\section{Authorship Contributions}

Concept: B.S., E.B., A.C.G., U.K., Design: B.S., E.B., U.K., Data Collection or Processing: B.S., E.B., A.C.G., U.K., Analysis or Interpretation: B.S., E.B., U.K., Literature Search: B.S., E.B., Writing: B.S., E.B., A.C.G., U.K.

Conflict of Interest: No conflict of interest was declared by the authors.

Financial Disclosure: The authors declared that this study received no financial support.

\section{References}

1. Borgia F, Giuffrida R, Guarneri F, Cannavò SP. Relapsing polychondritis: an updated review. Biomedicines 2018;6:84.

2. McAdam LP, O'Hanlan MA, Bluestone R, Pearson CM. Relapsing polychondritis: prospective study of 23 patients and a review of the literature. Medicine (Baltimore) 1976;55:193-215.

3. Hebbar M, Brouillard M, Wattel E, et al. Association of myelodysplastic syndrome and relapsing polychondritis: further evidence. Leukemia 1995;9:731-3.

4. Kent PD, Michet CJ Jr, Luthra HS. Relapsing polychondritis. Curr Opin Rheumatol 2004;16:56-61.

5. Masterson R, Sheerin N, Abbs I, Goldsmith D. Late allograft loss due to recurrence of $\mathrm{p}$-ANCA-associated systemic vasculitis in a patient with relapsing polychondritis. Nephrol Dial Transplant 2001;16:705-7.

6. Trentham DE, Le CH. Relapsing polychondritis. Ann Intern Med 1998;129:114-22.

7. Gross WL, Schmitt WH, Csernok E. ANCA and associated diseases: immunodiagnostic and pathogenetic aspects. Clin Exp Immunol 1993;91:1-12.

8. Papo T, Piette JC, Le Thi Huong Du, et al. Antineutrophil cytoplasmic antibodies in polychondritis. Ann Rheum Dis 1993;52:384-5.

9. Xuan YY, Li TF, Zhang L, Liu SY. ANCA positive relapsing polychondritis, Graves disease, and suspected moyamoya disease: A case report. Medicine (Baltimore) 2017;96:e9378. doi: 10.1097/ MD.0000000000009378.

10. File I, Trinn C, Mátyus Z, Ujhelyi L, Balla J, Mátyus J. Relapsing polychondritis with $\mathrm{p}$-ANCA associated vasculitis: which triggers the other? World J Clin Cases 2014;2:912-7.

11. Mattiassich G, Egger M, Semlitsch G, Rainer F. Occurrence of relapsing polychondritis with a rising cANCA titre in a cANCApositive systemic and cerebral vasculitis patient. BMJ Case Rep 2013;2013:bcr2013008717. doi: 10.1136/bcr-2013-008717

12. Cañas CA, Díaz-Martínez JC, Tobón GJ. Combination of hypertrophic pachymeningitis, PR3-ANCA-positive vasculitis, and relapsing polychondritis. J Rheumatol 2011;38:966-7.

13. Gao Y, Zhao MH. Review article: drug-induced anti-neutrophil cytoplasmic antibody-associated vasculitis. Nephrology (Carlton) 2009;14:33-41. 